\title{
Relationships between Walking, Body Mass Index, and Risk Factors of Metabolic Syndrome among Korean Adults: Data from the Fifth Korea National Health and Nutrition Examination Survey (2010-2012)
}

Dong-II Kim*

Department of Sport and Leisure Studies, Yonsei University, Seoul, Korea

Background: It is well known that obesity increases the risk of metabolic syndrome (MS); however, the associations between walking and MS risk factors among Korean adults still need to be elucidated. The purpose of this study was to examine the relationships of body mass index (BMI) and walking with MS risk factors among Korean adults from the fifth Korea national health and nutrition examination survey. Methods: A total of 17,019 (7,334 males, 9,685 females) Korean adults participated in the cross-sectional study. We measured walking, BMI, and MS risk factors including waist-circumference (WC), glucose, triglyceride (TG), high density lipoprotein cholesterol (HDL-C), systolic blood pressure (SBP), and diastolic blood pressure (DBP). Results: Results showed that 1$)$ subjects with high BMI $\left(23 \mathrm{~kg} / \mathrm{m}^{2} \leq \mathrm{BMI}\right)$ had significantly increased MS risk factors compared to subjects with low BMI $\left.\left(\mathrm{BMI}<23 \mathrm{~kg} / \mathrm{m}^{2}\right), 2\right)$ subjects who participated in walking had significantly decreased WC, TG and increased HDL-C compared to subjects who didn't participate in walking, and 3) when subjects were divided into four groups according to walking and BMI levels, subjects with nonparticipation in walking and high BMI showed the worst profile of metabolic syndrome risk factors. Moreover, subjects with nonparticipation in walking and high BMI had 7.42 times higher the prevalence of MS compared to subjects with participation in walking and low BMI after adjusted for age, sex, BMI, and smoking. Conclusion: Our study showed that improvement in walking and reduction in BMI are important factors for the prevention of metabolic syndrome in Korean adults.

Key words: Korean adults, Walking, BMI, Metabolic syndrome

\section{서 론}

2012년 국민건강통계 ${ }^{1}$ 에 따르면 만 19세 이상 성인의 비만 유병률 은 1998년 25.8\%에서 2005년 31.4\%로 급속하게 증가한 후 2012년까 지 $32.8 \%$ 의 비만 유병률을 유지하고 있다. 이와 같이 국내 성인들의 비만 유병률은 증가하고 있는 반면, 규칙적인 신체활동은 계속적으 로 감소하고 있는 실정이다. 걷기를 제외한 중등도 이상의 규칙적인
신체활동참여율은 2005 년 $18.7 \%$ 에서 2012년 6.6\%로 감소하였다. 특 히 규칙적인 걷기 참여율에서는 2005년 60.7\%에서 2012년 38.7\%로 크게 감소된 것으로 보고되었다.

비만은 대사증후군의 주요한 요인 중 하나이며 심혈관 질환 및 당뇨 병 발생에 밀접한 연관이 있다..$^{2-5} 20$ 세 이상의 성인남녀 3,423명을 대 상으로 한 $\operatorname{Ervin}^{3}$ 의 국외연구에서는 비만에 따른 대사증후군의 발생 률을 성별에 따라 살펴보았는데, 성인남성에서는 정상체중 그룹보다
Corresponding author Dong-II Kim

Department of Sport and Leisure Studies, Yonsei University, 50 Yonsei-ro, Seodaemun-Gu, Seoul 120-749, Korea

Tel +82-2-2123-6197 Fax +82-2-2123-8648 E-mail hiop1@hanmail.net

Received Jan. 28, 2015 Reviewed Feb. 9, 2015 Accepted Mar. 10, 2015
Copyright (C) 2015 Korean Society for the Study of Obesity

() This is an Open Access article distributed under the terms of the Creative Commons Attribution Non-Commercial License (http://creativecommons.org/licenses/by-nc/3.0/) which permits unrestricted non-commercial use, distribution, and reproduction in any medium, provided the original work is properly cited. 
비만한 그룹이 31.9배[Odd ratio; OR 31.92 (95\% confidence interval; CI, 20.06-50.78)] 높은 것으로 나타났으며 과체중 그룹에서는 6.1배 [OR 6.17 (95\% CI, 3.96-9.62)] 높은 것으로 나타났다. 또한 성인여성에 서는 비만한 그룹과 과체중 그룹이 정상체중 그룹보다 대사증후군 발 생률이 각각 17.1배[OR 17.14 (95\% CI, 12.54-23.44)], 5.4배[OR 5.48 (95\% CI, 3.75-8.02)]로 대사증후군 발생률이 증가한 것으로 나타났다.

비만 및 좌식활동의 증가는 대사증후군 발병률6을 높여주는 반면, 규칙적인 신체활동 참여로 인한 체력수준의 향상은 대사증후군 발 병률을 감소시킨다. ${ }^{78}$ 규칙적인 신체활동 중 걷기는 성인들이 장소와 시간의 제약을 받지 않는 경제적이고 효율적인 신체활동 중 하나이며 대사증후군 및 여러 성인병에도 긍정적인 개선 및 영향을 미친다.7-9 중년여성 72,488명을 대상으로 한 Manson 등 ${ }^{9}$ 의 연구에서는 주당 규 칙적인 걷기를 $10 \mathrm{MET}$-hours 이상 참여한 그룹이 주당 $0.5 \mathrm{MET}$ hours 이하로 참여한 그룹보다 대사증후군과 관련성이 있는 관상동 맥관련 질환이 $54 \%$ [Relative risk; RR 0.46 (95\% CI, 0.33-0.63)]의 감 소율이 나타났으며 나이, 비만도 그리고 흡연 등의 변인들을 통제한 후에도 35\% [RR, 0.65 (95\% CI, 0.47-0.91)]의 감소율을 보였다. 이와 같이 규칙적인 걷기를 통한 신체활동량의 증가는 비만, 근력 그리고 심폐체력에 긍정적인 개선 및 영향을 미치고 대사증후군 위험요인과 발생위험률을 낮추어준다.-9 특히 규칙적인 신체활동을 통한 체력의 증가와 비만의 감소는 대사증후군뿐만 아니라, 당뇨병 및 심혈관 질 환과 같은 여러 성인병에도 긍정적인 개선 및 영향을 준다.9-11

결론적으로, 비만도의 개선과 규칙적인 신체활동의 참여는 대사증 후군 및 각종 성인병에 긍정적인 개선 및 영향을 미친다. 국내에서 비 만도의 수준과 규칙적인 신체활동 참여에 따른 대사증후군 위험요인 과의 관계를 규명한 연구는 제한적으로나마 진행되어 왔다. ${ }^{12}$ 그럼에 도 불구하고 일반적인 연구에 비해 시간과 비용적인 측면이 많이 소 요되며 귀속 위험도와 비교 위험도를 직접 측정이 가능한 객관적 신 뢰도가 높은 대규모 코호트 연구를 이용하여 국내 성인들을 대상으 로 그 연관성을 조사한 연구는 매우 부족한 실정이다. 따라서 본 연구 에서는 2010년부터 2012년까지 조사한 제5기 국민건강영양조사자료 를 바탕으로 한국 성인들의 체질량지수와 규칙적인 걷기참여에 따른 대사증후군 위험요인 및 발생위험률에 미치는 영향을 규명하고자 하 는 데 그 목적이 있다.

\section{방 법}

\section{1. 연구대상}

본 연구는 제 5 기 국민건강영양조사(The Fifth Korea National Health and Nutrition Examination Survey, KNHANES V)의 자료를 이용하여 분석하였다. 본 연구에 사용된 데이터는 국민건강영양조사
Table 1. Subject characteristics

\begin{tabular}{lccr}
\hline Variables & Male $(\mathrm{N}=7,334)$ & Female $(\mathrm{N}=9,685)$ & $P$ value \\
\hline Age $($ year $)$ & $49.93 \pm 16.02$ & $49.09 \pm 16.13$ & 0.001 \\
Height $(\mathrm{cm})$ & $169.78 \pm 6.56$ & $156.77 \pm 6.52$ & $<0.001$ \\
Weight $(\mathrm{kg})$ & $69.43 \pm 10.93$ & $57.34 \pm 8.99$ & $<0.001$ \\
BMI $\left(\mathrm{kg} / \mathrm{m}^{2}\right)$ & $24.03 \pm 3.12$ & $23.34 \pm 3.48$ & $<0.001$ \\
Metabolic syndrome risk factors & & & \\
WC $(\mathrm{cm})$ & $84.49 \pm 8.85$ & $78.30 \pm 9.78$ & $<0.001$ \\
SBP $(\mathrm{mmHg})$ & $123.18 \pm 15.94$ & $118.38 \pm 18.18$ & $<0.001$ \\
DBP $(\mathrm{mmHg})$ & $79.75 \pm 10.64$ & $74.60 \pm 10.04$ & $<0.001$ \\
Glucose $(\mathrm{mg} / \mathrm{dL})$ & $100.50 \pm 23.99$ & $95.44 \pm 19.43$ & $<0.001$ \\
TC $(\mathrm{mg} / \mathrm{dL})$ & $187.56 \pm 36.75$ & $189.95 \pm 36.38$ & $<0.001$ \\
TG (mg/dL) & $156.99 \pm 136.38$ & $113.33 \pm 76.37$ & $<0.001$ \\
HDL-C (mg/dL) & $49.01 \pm 11.95$ & $55.10 \pm 12.76$ & $<0.001$ \\
Lifestyle factors & & & \\
Obesity & $2,623(35.7 \%)$ & $2,745(28.3 \%)$ & $<0.001$ \\
Smoking & $3,042(41.4 \%)$ & $490(5.0 \%)$ & $<0.001$ \\
Drinking & $5,407(73.7 \%)$ & $3,665(37.8 \%)$ & $<0.001$ \\
\hline
\end{tabular}

Data are Mean \pm SD

BMI, body mass index; WC, waist circumference; SBP, systolic blood pressure; DBP, diastolic blood pressure; TC, total cholesterol; TG, triglyceride; HDL-C, high density lipoprotein cholesterol.

홈페이지(https://knhanes.cdc.go.kr)에 제시된 절차에 따라 서약서 및 이용계획서를 작성한 후 제공받았고 2010년부터 2012년도의 제5 기 국민건강영양조사 자료를 결합하여 만들어진 통합자료를 이용하 여 본 연구에서 비교, 분석하였다. 전체 25,974 명의 응답자 중 만 19 세 이상의 성인을 대상으로 규칙적인 걷기 실천율, 체지방지수 그리고 대 사증후군 관련 위험요인(허리둘레, 수축기 혈압, 이완기 혈압, 중성지 방, 고밀도 지단백 콜레스테롤, 공복혈당)자료가 없는 8,955 명을 제외 한 17,019 명을 대상으로 분석하였다. 연구 대상자들의 신체적 특성은 Table 1과 같다.

\section{2. 측정항목}

질병관리본부로부터 제공받은 2010년부터 2012년까지의 제 5 기 국 민건강영양조사 원시자료를 이용하여 비교 분석하였다. 본 연구의 대 상자들의 인구사회학적 특성 및 건강행태의 변수인 성별, 나이, 생활 습관 등을 비교 분석하였고 허리둘레, 체질량지수, 총 콜레스테롤, 공 복혈당, 혈압, 고밀도 지단백 콜레스테롤 그리고 중성지방의 검체 분 석결과 및 계측자료를 이용하여 비교 분석하였다. 마지막으로 대상자 들의 규칙적인 걷기 실천율을 비교 분석하였다.

\section{1) 대사증후군 위험요인 측정}

대사증후군 위험요인들은 다음과 같이 측정하였다. 1) 허리둘레는 줄자(seca 200, seca, Germany)를 이용하여 소수점 한 자리 $(0.1 \mathrm{~cm})$ 까 지 측정하였다. 2) 혈압은 의자에 앉은 상태에서 5 분의 안정기간을 가 
진 후 혈압계(Baumanometer ${ }^{\circledR}$ Desk model 0320, Baum, USA)를 이 용하여 혈압을 측정하였고 5 분 간격으로 3 회 측정하였다. 본 연구에 서는 2 차와 3 차에 측정된 혈압의 평균값을 사용하였다. 3) 혈액검사 는 최소 8 시간 이상 금식 후 혈액을 채취하였다. 혈액채취 후 실온에 30 분간 세워 둔 후 $3,000 \mathrm{rpm}$ 으로 15 분간 원심분리 후 분석하였다. 혈액검사를 통해 수집된 항목은 공복 혈당, 고밀도 지단백 콜레스테 롤, 중성지방 그리고 총 콜레스테롤이다.

\section{2) 대사증후군}

공복 혈당(공복 시 혈당 $\geq 110 \mathrm{mg} / \mathrm{dL}$ ), 아시아 기준 ${ }^{13}$ 의 허리둘레(남 자 $\geq 90 \mathrm{~cm}$, 여자 $\geq 80 \mathrm{~cm}$ ), 혈압(수축기/이완기 혈압 $\geq 130 / 85 \mathrm{mmHg}$ ), 중성지방 $\geq 150 \mathrm{mg} / \mathrm{dL}$ ) 그리고 고밀도 지단백 콜레스테롤(남자<40 $\mathrm{mg} / \mathrm{dL}$, 여자 $<50 \mathrm{mg} / \mathrm{dL}$ ) 중 3 가지 이상에 해당되는 경우 대사증후군 이라고 진단하였다. 대사증후군 진단기준은 National Cholesterol Education Program Adults Treatment Panel $\mathrm{III}^{14}$ 에서 제시한 가이드라 인을 이용하여 정의 내렸다.

\section{3)규칙적인 걷기 참여 유무}

세계보건기구(WHO) ${ }^{15}$ 에서 발표한 '건강을 위한 신체활동 권고안 (Global Recommendation on Physical Activity for Health)'에서는 성 인 및 노인들의 규칙적인 신체활동 참여의 기간은 최소 일주일에 150 분 이상의 참여를 권고하였다. 따라서 본 연구에서는 규칙적인 걷기 참여 유무를 측정하기 위해서 다음과 같은 방법으로 분석하였다. 규 칙적인 걷기 참여는 걷기 실천율을 분석하여 정의하였으며 기준은 '최근 1 주일 동안 걷기를 1 회 30 분 이상, 주 5 일 이상 실천하는 것'에 해당되는 경우, 규칙적인 걷기에 참여한 것으로 정의 내렸다.

\section{3. 자료처리방법}

통계분석은 SPSS/Window 18.0을 사용하였다. 규칙적인 걷기와 체 질량지수에 따른 대사증후군 위험요인 및 발생위험률에 미치는 영향 을 알아보기 위하여 Independent $t$-test를 사용하여 성별에 따른 각 그 룹 간의 측정항목 요인들의 평균값을 비교 분석하였다. 국내를 포함한 일부 아시아 지역에서는 체질량지수가 $18.5-23 \mathrm{~kg} / \mathrm{m}^{2}$ 미만을 정상체 중, $23-24.9 \mathrm{~kg} / \mathrm{m}^{2}$ 를 과체중 그리고 $25 \mathrm{~kg} / \mathrm{m}^{2}$ 이상을 비만으로 정의 내 린다. ${ }^{16}$ 따라서 규칙적인 걷기 참여 유무와 체질량지수 $23 \mathrm{~kg} / \mathrm{m}^{2}$ 을 기 준으로 (1)규칙적인 걷기와 정상체중 $\left(\mathrm{BMI}<23 \mathrm{~kg} / \mathrm{m}^{2}\right)$, (2)규칙적인 걷 기 참여와 과체중 이상 $\left(23 \mathrm{~kg} / \mathrm{m}^{2} \leq \mathrm{BMI}\right)$, (3)규칙적인 걷기 비참여와 정상체중 $\left(\mathrm{BMI}<23 \mathrm{~kg} / \mathrm{m}^{2}\right)$, (4)규칙적인 걷기 비참여와 과체중 이상 $\left(23 \mathrm{~kg} / \mathrm{m}^{2} \leq \mathrm{BMI}\right)$ 그룹으로 총 4 그룹으로 나누었으며 ANCOVA를 이 용하여 나이, 성별 그리고 흡연을 통제한 상태에서 그룹 간에 대사증 후군 위험요인들을 비교 분석하였다. 마지막으로, 나이, 성별 그리고 흡연을 통제한 후 로지스틱 회귀분석(Logistic Regression)을 실시하 여 규칙적인 걷기와 체질량지수에 따른 대사증후군 유병률의 Odd Ratio를 측정하였으며 '규칙적인 걷기와 정상체중' 그룹을 기준으로 분석하였다. 본 연구의 통계적으로 유의수준은 $P<0.05$ 로 설정하였다.

\section{결 과}

\section{1. 체질량지수에 따른 대사증후군 위험요인과의 관계}

본 연구에서는 대상자들의 체질량지수에 따른 대사증후군 위험요 인의 차이를 Table 2 와 같이 제시하였다. 성인남성에서는 정상체중 $\left(\mathrm{BMI}<23 \mathrm{~kg} / \mathrm{m}^{2}\right)$ 그룹이 과체중 이상 $\left(23 \mathrm{~kg} / \mathrm{m}^{2} \leq \mathrm{BMI}\right)$ 그룹보다 허 리둘레, 수축기 혈압, 이완기 혈압, 공복혈당, 총 콜레스테롤 그리고 중

Table 2. Clinical and metabolic syndrome risk factors of participants based on their BMI

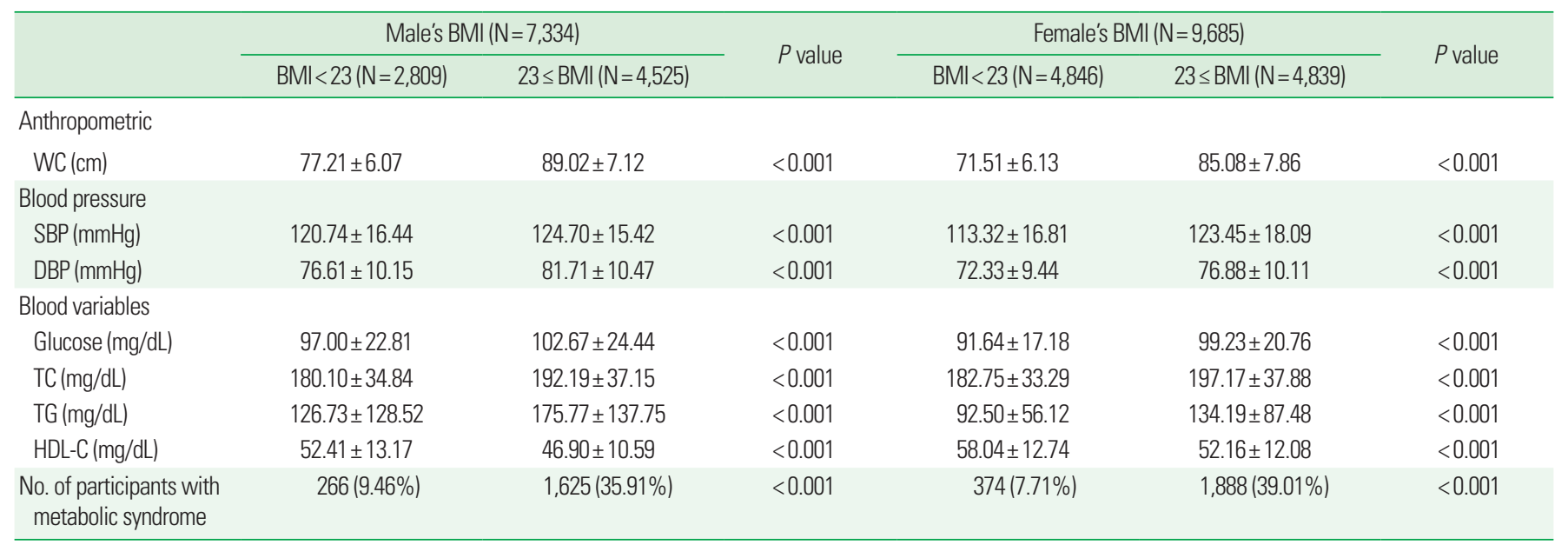

Data are Mean \pm SD

BMI, body mass index; WC, waist circumference; SBP, systolic blood pressure; DBP, diastolic blood pressure; TC, total cholesterol; TG, triglyceride; HDL-C, high density lipoprotein cholesterol. 
성지방에서 유의하게 낮게 나타났으며 고밀도 지단백 콜레스테롤에 서는 유의하게 높게 나타났다. 또한 성인여성에서는 정상체중 $\left(\mathrm{BMI}<23 \mathrm{~kg} / \mathrm{m}^{2}\right)$ 그룹이 과체중 이상 $\left(23 \mathrm{~kg} / \mathrm{m}^{2} \leq \mathrm{BMI}\right)$ 그룹보다 허 리둘레, 수축기 혈압, 이완기 혈압, 공복혈당, 총 콜레스테롤 그리고 중 성지방에서 유의하게 낮게 나타났으며 고밀도 지단백 콜레스테롤에 서는 유의하게 높게 나타났다.

\section{2. 규칙적인 걷기 참여에 따른 대사증후군 위험요인과의 관계}

본 연구에서는 규칙적인 걷기 참여에 따른 대사증후군 위험요인 간의 차이를 Table 3 과 같이 제시하였다. 성인남성에서는 규칙적인 걷 기 참여 그룹이 비참여 그룹보다 체질량지수, 허리둘레, 총 콜레스테 롤 그리고 중성지방에서 유의하게 낮게 나타났고 고밀도 지단백 콜레 스테롤에서는 높게 나타났으며 두 그룹 간에 유의한 차이가 있었다.
또한 성인여성에서는 규칙적인 걷기 참여 그룹이 비참여 그룹보다 허 리둘레와 중성지방에서 유의하게 낮았으며 고밀도 지단백 콜레스테 롤에서는 유의하게 높았고 두 그룹 간에 유의한 차이가 있었다.

\section{3. 규칙적인 걷기 참여와 체질량지수에 따른 대사증후군 위험요인에 미치는 영향}

본 연구에서는 대상자들의 규칙적인 걷기 참여와 체질량지수를 (1) 규칙적인 걷기와 정상체중 $\left(\mathrm{BMI}<23 \mathrm{~kg} / \mathrm{m}^{2}\right)$, (2)규칙적인 걷기 참여 와 과체중 이상 $\left(23 \mathrm{~kg} / \mathrm{m}^{2} \leq \mathrm{BMI}\right)$, (3)규칙적인 걷기 비참여와 정상체 중 $\left(\mathrm{BMI}<23 \mathrm{~kg} / \mathrm{m}^{2}\right)$, (4)규칙적인 걷기 비참여와 과체중 이상 $(23 \mathrm{~kg} /$ $\left.\mathrm{m}^{2} \leq \mathrm{BMI}\right)$ 그룹으로 나누었다. 나이, 성별 그리고 흡연을 통제한 후, 각 그룹 간의 대사증후군 위험요인의 차이를 Table 4 와 같이 비교 분 석하였다. '규칙적인 걷기와 정상체중 $\left(\mathrm{BMI}<23 \mathrm{~kg} / \mathrm{m}^{2}\right)$ ' 그룹이 '규칙

Table 3. Clinical and metabolic syndrome risk factors of participants based on their walking

\begin{tabular}{|c|c|c|c|c|c|c|}
\hline & \multicolumn{2}{|c|}{ Male's walking $(\mathrm{N}=7,334)$} & \multirow{2}{*}{$P$ value } & \multicolumn{2}{|c|}{ Female's walking $(\mathrm{N}=9,685)$} & \multirow{2}{*}{$P$ value } \\
\hline & Yes (N=3,042) & No (N=4,292) & & Yes (N=3,629) & No $(N=6,056)$ & \\
\hline \multicolumn{7}{|l|}{ Anthropometric } \\
\hline $\mathrm{BMI}\left(\mathrm{kg} / \mathrm{m}^{2}\right)$ & $23.90 \pm 3.06$ & $24.12 \pm 3.16$ & 0.003 & $23.32 \pm 3.45$ & $23.36 \pm 3.50$ & 0.556 \\
\hline$W C(\mathrm{~cm})$ & $83.94 \pm 8.64$ & $84.88 \pm 8.98$ & $<0.001$ & $77.96 \pm 9.69$ & $78.50 \pm 9.83$ & 0.010 \\
\hline \multicolumn{7}{|l|}{ Blood pressure } \\
\hline $\mathrm{SBP}(\mathrm{mmHg})$ & $123.76 \pm 16.29$ & $122.77 \pm 15.67$ & 0.009 & $118.11 \pm 17.99$ & $118.54 \pm 18.30$ & 0.254 \\
\hline $\mathrm{DBP}(\mathrm{mmHg})$ & $79.51 \pm 10.70$ & $79.92 \pm 10.59$ & 0.103 & $74.53 \pm 10.04$ & $74.64 \pm 10.04$ & 0.580 \\
\hline \multicolumn{7}{|l|}{ Blood variables } \\
\hline Glucose (mg/dL) & $100.48 \pm 25.31$ & $100.51 \pm 23.01$ & 0.953 & $95.28 \pm 19.94$ & $95.53 \pm 19.12$ & 0.533 \\
\hline $\mathrm{TC}(\mathrm{mg} / \mathrm{dL})$ & $186.34 \pm 37.21$ & $188.43 \pm 36.40$ & 0.016 & $189.53 \pm 36.39$ & $190.21 \pm 36.37$ & 0.376 \\
\hline $\mathrm{TG}(\mathrm{mg} / \mathrm{dL})$ & $150.74 \pm 150.15$ & $161.41 \pm 125.55$ & 0.001 & $109.45 \pm 81.26$ & $115.66 \pm 73.20$ & $<0.001$ \\
\hline $\mathrm{HDL}-\mathrm{C}(\mathrm{mg} / \mathrm{dL})$ & $49.89 \pm 12.39$ & $48.38 \pm 11.59$ & $<0.001$ & $55.98 \pm 13.26$ & $54.57 \pm 12.42$ & $<0.001$ \\
\hline $\begin{array}{l}\text { No. of participants with } \\
\text { metabolic syndrome }\end{array}$ & $760(24.98 \%)$ & $1,131(26.35 \%)$ & 0.186 & $815(22.45 \%)$ & $1,447(23.89 \%)$ & 0.104 \\
\hline
\end{tabular}

Data are Mean \pm SD.

BMI, body mass index; WC, waist circumference; SBP, systolic blood pressure; DBP, diastolic blood pressure; TC, total cholesterol; TG, triglyceride; HDL-C, high density lipoprotein cholesterol.

Table 4. Metabolic syndrome risk factors of participants based on their BMl and walking

\begin{tabular}{|c|c|c|c|c|}
\hline \multirow{2}{*}{ Total $(\mathrm{N}=17,019)$} & \multicolumn{2}{|c|}{ Participation in Walking } & \multicolumn{2}{|c|}{ Nonparticipation in Walking } \\
\hline & $\mathrm{BMl}<23(\mathrm{~N}=3,006)$ & $23 \leq \mathrm{BMI}(\mathrm{N}=4,649)$ & $\mathrm{BMl}<23(\mathrm{~N}=3,665)$ & $23 \leq \mathrm{BMI}(\mathrm{N}=5,699)$ \\
\hline \multicolumn{5}{|l|}{ Metabolic syndrome risk factors } \\
\hline$W C(\mathrm{~cm})$ & $73.94 \pm 0.12$ & $74.37 \pm 0.09^{*}$ & $86.07 \pm 0.11^{*+}$ & $86.78 \pm 0.08^{*+\neq}$ \\
\hline $\mathrm{SBP}(\mathrm{mmHg})$ & $117.65 \pm 0.27$ & $117.55 \pm 0.21$ & $123.29 \pm 0.24^{* \dagger}$ & $122.47 \pm 0.19^{*+\neq}$ \\
\hline $\mathrm{DBP}(\mathrm{mmHg})$ & $74.06 \pm 0.18$ & $74.52 \pm 0.14^{*}$ & $78.87 \pm 0.16^{* \dagger}$ & $78.84 \pm 0.13^{* \dagger}$ \\
\hline Glucose (mg/dL) & $94.63 \pm 0.37$ & $94.73 \pm 0.30$ & $100.11 \pm 0.34^{* \dagger}$ & $99.94 \pm 0.27^{* \dagger}$ \\
\hline $\mathrm{TG}(\mathrm{mg} / \mathrm{dL})$ & $103.37 \pm 1.89$ & $112.47 \pm 1.52^{*}$ & $147.57 \pm 1.71^{* \dagger}$ & $153.45 \pm 1.37^{*+\neq}$ \\
\hline $\mathrm{HDL}-\mathrm{C}(\mathrm{mg} / \mathrm{dL})$ & $56.60 \pm 0.21$ & $54.56 \pm 0.17^{*}$ & $50.61 \pm 0.19^{* \dagger}$ & $49.79 \pm 0.15^{* \neq \ddagger}$ \\
\hline No. of participants with metabolic syndrome & $215(7.15 \%)$ & $425(9.14 \%)$ & $1,360(37.10 \%)^{*+}$ & $2,153(37.77 \%)^{*}$ \\
\hline
\end{tabular}

Data are Mean \pm SE.

BMI, body mass index; WC, waist circumference; SBP, systolic blood pressure; DBP, diastolic blood pressure; TG, triglyceride; HDL-C, high density lipoprotein cholesterol. ${ }^{*}$ significantly different from first group, ${ }^{\dagger}$ significantly different from second group, ${ }^{\ddagger}$ significantly different from third group.

Adjusted for age, sex, and smoking, $P<0.05$. 
적인 걷기 비 참여와 과체중 이상 $\left(23 \mathrm{~kg} / \mathrm{m}^{2} \leq \mathrm{BMI}\right)^{\prime}$ 그룹보다 허리둘 레, 수축기 혈압, 이완기 혈압, 공복혈당, 중성지방 그리고 대사증후군 발생 수에서 유의하게 낮게 나타났으며 고밀도 지단백 콜레스테롤에 서는 유의하게 높게 나타났고 그룹 간의 유의한 차이가 있었다.

\section{4. 규칙적인 걷기와 체질량지수에 따른 대사증후군 발생위험률}

본 연구에서는 대상자들의 규칙적인 걷기 참여와 체질량지수를 (1) 규칙적인 걷기와 정상체중 $\left(\mathrm{BMI}<23 \mathrm{~kg} / \mathrm{m}^{2}\right)$, (2)규칙적인 걷기 참여 와 과체중 이상 $\left(23 \mathrm{~kg} / \mathrm{m}^{2} \leq \mathrm{BMI}\right)$, (3)규칙적인 걷기 비참여와 정상체 중 $\left(\mathrm{BMI}<23 \mathrm{~kg} / \mathrm{m}^{2}\right)$, (4)규칙적인 걷기 비참여와 과체중 이상 $(23 \mathrm{~kg} /$ $\left.\mathrm{m}^{2} \leq \mathrm{BMI}\right)$ 그룹으로 나누어 각 그룹 간에 따른 대사증후군 발생위험 률을 Fig. 1과 같이 제시하였다. '규칙적인 걷기 비참여와 과체중 이상 $\left(23 \mathrm{~kg} / \mathrm{m}^{2} \leq \mathrm{BMI}\right)$ ' 그룹이 '규칙적인 걷기와 정상체중 $(\mathrm{BMI}<23 \mathrm{~kg} /$ $\left.\mathrm{m}^{2}\right)^{\prime}$ 그룹보다 대사증후군 발생위험률이 7.88배[OR $7.88(95 \% \mathrm{CI}$, 6.79-9.14)] 높은 것으로 나타났고, 나이, 성별 그리고 흡연을 통제한 후에도 7.42배[OR $7.42(95 \% \mathrm{CI}, 6.38-8.63)]$ 높은 것으로 나타났다.

\section{고 찰}

본 연구의 목적은 2010년부터 2012년까지 수집된 제5기 국민건강 영양조사 자료를 바탕으로 체질량지수와 규칙적인 걷기에 따른 대사 증후군 위험요인 및 발생위험률에 어떠한 영향을 미치는지를 규명하 는 것이다. 본 연구의 결과, 정상체중 $\left(\mathrm{BMI}<23 \mathrm{~kg} / \mathrm{m}^{2}\right)$ 그룹이 과체중 이상 $\left(23 \mathrm{~kg} / \mathrm{m}^{2} \leq \mathrm{BMI}\right)$ 그룹보다 허리둘레, 수축기 혈압, 이완기 혈압,

\section{*Model 1: Crude OR $(95 \% \mathrm{Cl})$}

OR: $7.88(6.79-9.14)$

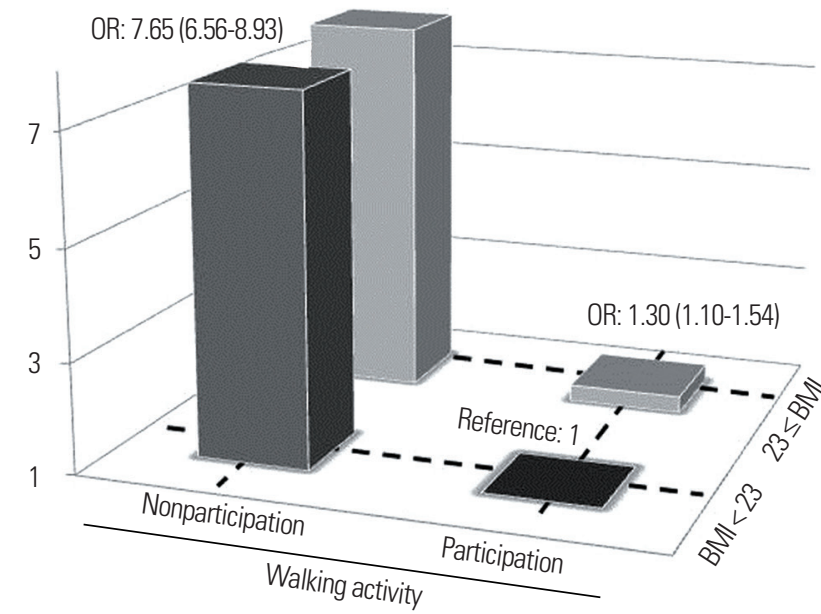

Fig. 1. Prevalence of the metabolic syndrome according to walking and BMI. $\mathrm{OR}$, odds ratio; $\mathrm{Cl}$, confidence interval; $\mathrm{BMI}$, body mass index. By logistic regression adjusted for age, sex, and smoking.
공복혈당, 총 콜레스테롤 그리고 중성지방에서 유의하게 낮게 나타났 으며 고밀도 지단백 콜레스테롤에서는 유의하게 높게 나타났다. 성별 에 따른 대사증후군 위험요인의 차이를 살펴본 결과, 성인남성에서는 규칙적인 걷기 참여 그룹이 비참여 그룹보다 체질량지수, 허리둘레, 수축기 혈압, 총 콜레스테롤 그리고 중성지방에서 유의하게 낮게 나 타났으며 고밀도 지단백 콜레스테롤에서는 유의하게 높게 나타났다. 또한 성인여성에서는 규칙적인 걷기 참여 그룹이 비참여 그룹보다 허 리둘레와 중성지방에서 유의하게 감소하였으며 고밀도 지단백 콜레 스테롤에서는 유의하게 증가하였다. 체질량지수와 규칙적인 걷기 참 여 유무를 나누어 총 4 그룹으로 나누고 나이, 성별, 체질량지수 그리 고 흡연을 통제한 후 분석해본 결과, '규칙적인 걷기와 정상체중 $\left(\mathrm{BMI}<23 \mathrm{~kg} / \mathrm{m}^{2}\right)$ ' 그룹이 '규칙적인 걷기 비참여와 과체중 이상 $(23$ $\left.\mathrm{kg} / \mathrm{m}^{2} \leq \mathrm{BMI}\right)^{\prime}$ 그룹보다 허리둘레, 수축기 혈압, 이완기 혈압, 공복혈 당, 중성지방 그리고 대사증후군 발생 수에서 유의하게 낮게 나타났 으며 고밀도 지단백 콜레스테롤에서는 유의하게 높게 나타났고 그룹 간의 유의한 차이가 있었다. 마지막으로 규칙적인 걷기와 체질량지수 에 따른 대사증후군의 발생위험률을 비교 분석해본 결과, '규칙적인 걷기 비참여와 과체중 이상 $\left(23 \mathrm{~kg} / \mathrm{m}^{2} \leq \mathrm{BMI}\right)$ ' 그룹이 '규칙적인 걷기 와 정상체중 $\left(\mathrm{BMI}<23 \mathrm{~kg} / \mathrm{m}^{2}\right)^{\prime}$ 그룹보다 대사증후군 발생위험률이 7.88 배 높은 것으로 나타났고, 나이, 성별 그리고 흡연을 통제한 후에 도 7.42배 유의하게 높은 것으로 나타났다.

비만의 증가는 대사증후군 위험요인 및 발생률에 부정적인 영향을 미친다. ${ }^{2,3}$ 특히 3,035 명의 노인들을 대상으로 한 Goodpaster 등긔 의 연 구에서는 남성의 경우, 정상체중 그룹은 $12 \%$, 과체중 그룹은 $36 \%$ 그

${ }^{*}$ Model 2: Adjusted OR (95\% Cl)

OR: 7.42 (6.38-8.63)

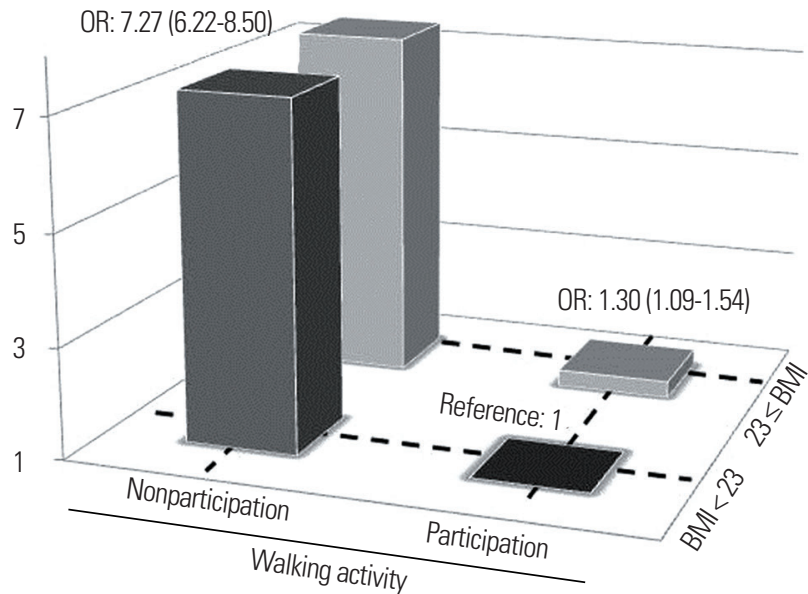


리고 비만 그룹은 $62 \%$ 로 대사증후군이 발병하였으며 여성의 경우, 정상체중 그룹은 $22 \%$, 과체중 그룹은 $46 \%$ 그리고 비만 그룹은 $61 \%$ 로 대사증후군이 발병하였다. 즉, 체질량지수가 개선될수록 그에 따 른 대사증후군 발병률 또한 감소하였다. 본 연구의 결과에서도 정상 체중 $\left(\mathrm{BMI}<23 \mathrm{~kg} / \mathrm{m}^{2}\right)$ 그룹이 과체중 이상 $\left(23 \mathrm{~kg} / \mathrm{m}^{2} \leq \mathrm{BMI}\right)$ 그룹보 다 대사증후군 위험요인의 모든 변인에서 긍정적인 수치를 나타냈다.

규칙적인 걷기의 참여는 심폐체력 및 근력을 향상시켜주는 효과를 주며 대사증후군 및 당뇨병과 같은 각종 성인병들의 발생위험률을 낮 추어 준다.7.8,18,19 걷기, 체력, 비만 그리고 안정 시 심박수와 관련되어 진 RCT연구 24 개를 메타 분석한 Murphy 등 20 의 연구에서는 걷기의 참여는 심폐체력 $\left(\mathrm{VO}_{2} \max \right)$ 을 강화시켜주고 체중과 체질량지수 그리 고 안정 시 심박수를 유의하게 낮추어 준다고 보고되었다. 이와 같이 규칙적인 신체활동은 혈관내피세포 기능을 개선시키고 인슐린저항 성에 의한 교감신경의 활성화를 억제시킴과 동시에 부교감신경을 개 선시키므로 혈압에 긍정적인 영향을 준다. ${ }^{21,22}$ 또한 제 2 형 당뇨병환자 52 명(운동군: 26 명, 대조군: 26 명)을 대상으로 4 개월간 주당 3 일, 하루 에 45-60분의 규칙적인 걷기를 중재한 Fritz 등23의 연구에서는 전체 운동프로그램의 $80 \%$ 이상 참여한 대상자들의 수축기 혈압[mean difference $-7.6 \mathrm{mmHg}(95 \% \mathrm{CI},-15.0$ to -0.2$)]$, 이완기 혈압(-4.3 $\mathrm{mmHg},-7.4$ to -1.2$)$, 체질량지수 $\left(-0.6 \mathrm{~kg} / \mathrm{m}^{2},-1.1\right.$ to -0.1) 그리고 총 콜 레스테롤 $(-0.6 \mathrm{mmol} / \mathrm{l},-0.9$ to -0.3$)$ 에서 유의하게 감소되어진 것으로 보고되었다. 이와 같은 본 연구에서도 선행연구들과 같은 결과가 나 타났는데, 규칙적인 걷기 참여 그룹이 비참여 그룹보다 허리둘레, 체 질량지수, 수축기 혈압 그리고 중성지방 등에서 유의하게 감소하였고 특히, 고밀도 지단백 콜레스테롤에서는 유의하게 증가하였다. 이와 같이 고밀도 지단백 콜레스테롤의 증가는 저밀도 지단백 콜레스테롤 과 같은 나쁜 콜레스테롤을 혈관에서 회수하여 간으로 이동시키는 기능을 개선시키고 동맥벽의 기능을 강화시키는 역할을 한다. 또한 동맥경화등과 같은 심혈관계 질환의 발생위험률을 낮추어 준다. ${ }^{24}$

규칙적인 걷기참여는 신체활동의 증가와 함께 체력의 증가를 의미 하며, 체력의 증가로 인한 신체조성 및 생리적 변화는 대사증후군 위 험요인들의 위험률을 낮추어 준다.,10,20 국내 후기 청소년 남자들 453 명(나이: 18.64 \pm 0.76 )을 대상으로 한 Kim 등'2의 연구에서는 '낮은 체 력과 높은 비만도' 그룹, ‘높은 체력과 높은 비만도' 그룹 그리고 ‘낮은 체력과 낮은 비만도' 그룹이 '높은 체력과 낮은 비만도' 그룹(Reference: 1)보다 대상증후군위험요인 중 1 개 이상 발생할 확률이 각각 4.1 배[OR 4.13 (95\% CI, 2.48-6.85)], 1.9배[OR 1.91 (95\% CI, 1.09-3.33)], 1.7배[OR 1.77 (95\% CI, 0.84-3.74)]로 높은 것으로 나타났다. 본 연구 에서도 체력과 밀접한 관계가 있는 규칙적인 걷기와 체질량지수에 따 른 대사증후군의 발생위험률을 나이, 성별 그리고 흡연을 통제한 후 살펴보았는데, '규칙적인 걷기 비참여와 과체중 이상 $\left(23 \mathrm{~kg} / \mathrm{m}^{2} \leq\right.$
$\mathrm{BMI})$ 그룹이 '규칙적인 걷기와 정상체중 $\left(\mathrm{BMI}<23 \mathrm{~kg} / \mathrm{m}^{2}\right)$ ' 그룹보다 대사증후군 발생위험률이 7.42배 유의하게 높은 것으로 나타났다.

본 연구에서는 Fig. 1과 같이, 규칙적인 걷기에 참여하는 그룹 중 '과 체중 이상' 그룹이 '정상체중' 그룹(Reference: 1)보다 대사증후군 발 생위험률이 1.3배[OR $1.30(95 \%$ CI, 1.09-1.54)] 증가하는 것으로 나타 났으며 정상체중에 속한 그룹에서는 '규칙적인 걷기 비참여' 그룹이 '규칙적인 걷기 참여' 그룹(Reference: 1)보다 대사증후군 발생위험률 이 7.27배[OR $7.27(95 \% \mathrm{CI}, 6.22-8.50)]$ 증가하는 것으로 나타났다. 이 와 같이 규칙적인 신체활동의 참여와 비만도의 조절은 대사증후군 발생위험률에 긍정적인 영향을 줄 수 있다는 것을 시사하는 바이다. 또한 체력과 연관성이 높은 규칙적인 신체활동의 참여가 비만도의 조 절보다 대사증후군 발생위험률에 보다 많은 영향력을 줄 수 있음을 유추해 볼 수 있고 이러한 결과는 국내외의 여러 선행연구들 ${ }^{12,25}$ 에서 도 보고되었다. 특히, 88,393 명의 중년여성을 대상으로 한 $\mathrm{Li}$ 등 25 의 국 외연구에서는 '높은 신체활동(주당 3.5 시간 이상 참여)과 낮은 체질 량지수 $\left(18.5 \mathrm{~kg} / \mathrm{m}^{2} \leq \mathrm{BMI} \leq 24.9 \mathrm{~kg} / \mathrm{m}^{2}\right.$ )' 그룹이 '낮은 신체활동(주당 1 시간 이하 참여)과 낮은 체질량지수’ 그룹보다 관상동맥성심장병의 발생률이 1.48 배[RR $1.48(95 \%$ CI, 1.24-1.77)] 유의하게 높은 것으로 보고되었다.

본 연구에는 몇 가지 제한 점을 가지고 있다. 첫째로 본 연구는 규칙 적인 걷기활동에 따른 대사증후군과의 관계를 규명하는 연구이기 때 문에 신체활동의 종류를 걷기로 한정하였으며 그 외의 다른 신체활 동으로 확대 해석할 수 없다. 두 번째로는 본 연구의 대상자의 나이가 만 19세 이상의 성인이기 때문에 만 19세 미만의 청소년을 대상으로 확대 해석할 수 없다. 마지막으로 본 연구는 체질량지수와 규칙적인 걷기 참여에 따른 대사증후군 위험요인 및 발생 위험률의 관계에 대 해서만 규명되었고 원인과 결과에 대해 규명하지 않았기 때문에 인과 관계를 밝힐 수 없었다. 이러한 연구의 제한 점들에도 불구하고 본 연 구는 2010년부터 2012년까지의 제 5 기 국민건강영양조사의 자료를 바 탕으로 대규모 코호트의 샘플 수를 확보할 수 있었으며 체질량지수 와 규칙적인 걷기참여에 따른 대사증후군 위험요인과 발생 위험률과 의 관계를 규명하였다.

결론적으로, 비만도의 감소와 규칙적인 걷기의 참여는 대사증후군 위험요인에 긍정적인 영향을 주고 발생위험률을 낮추어 준다. 본 연구 의 결과를 종합해보면, 첫째, 체질량지수가 낮을수록 대사증후군 위 험요인에 긍정적인 영향을 준 것으로 나타났다. 두 번째, 규칙적인 걷 기참여는 대사증후군 위험요인에 긍정적인 영향을 준 것으로 나타났 다. 세 번째, '규칙적인 걷기와 정상체중' 그룹이 '규칙적인 걷기 비참 여와 과체중 이상' 그룹보다 대사증후군 위험요인 및 발생위험률에 긍정적인 영향을 준 것으로 나타났다. 마지막으로, 규칙적인 걷기의 참여가 체질량지수의 조절보다 대사증후군 발생위험률에 더 많은 영 
향을 준 것으로 유추해 볼수 있다.

국내 성인들의 비만도는 계속적으로 증가하고 있는 반면, 신체활동 량은 감소되고 있는 추세이다. 이로 인하여 대사증후군 및 당뇨병등 과 같은 각종 성인병들의 발생률이 증가하고 있다. 따라서 규칙적인 신체활동인 걷기의 참여와 더불어 비만도의 조절은 대사증후군 및 여러 성인병들을 예방하고 개선하는 데 매우 효과적인 방법이다.

\section{요 약}

배경: 한국 성인 비만 증가율은 급속하게 증가하고 있으나 신체활동 의 참여율은 감소되고 있는 추세이다. 이러한 현상들은 대사증후군 위험요인들에 부정적인 영향을 미치고 있으나 이와 관련 되어진 대규 모 코호트 연구는 매우 부족한 실정이다. 따라서 본 연구의 목적은 한 국 성인을 대상으로 규칙적인 걷기와 체질량지수에 따른 대사증후군 위험요인과의 관계를 알아보는데 있다.

방법: 총 17,019 명의 국내 성인들(남성: 7,334명, 여성: 9,685명)이 본 연 구에 참여하였으며, 대상자들의 신체구성, 체질량지수, 규칙적인 걷 기 그리고 대사증후군 위험요인 다섯 가지(허리둘레, 공복 시 혈당, 중 성지방, 고밀도 지단백 콜레스테롤, 수축기 혈압, 이완기 혈압)를 측정 하였다.

결과: 본 연구의 결과는 다음과 같다. 첫째, 체질량지수가 낮을수록 대사증후군 위험요인에 긍정적인 영향을 주었다. 두 번째, 규칙적인 걷기 참여는 대사증후군 위험요인에 긍정적인 영향을 주었다. 마지막 으로, '규칙적인 걷기 참여와 정상체중 $\left(\mathrm{BMI}<23 \mathrm{~kg} / \mathrm{m}^{2}\right)$ ' 그룹이 '규 칙적인 걷기 비참여와 과체중 이상 $\left(23 \mathrm{~kg} / \mathrm{m}^{2} \leq \mathrm{BMI}\right)^{\prime}$ 그룹보다 대사 증후군 발생위험률이 7.88배(95\% confidence interval; CI, 6.79-9.14) 높은 것으로 나타났고, 나이, 성별, 체질량지수 그리고 흡연을 통제한 후에도 7.42배( $95 \% \mathrm{CI}, 6.38-8.63)$ 유의하게 높은 것으로 나타났다.

결론: 본 연구는 국내 성인들의 규칙적인 걷기의 비참여와 체질량지 수의 증가는 대사증후군 위험요인 및 발생위험률에 부정적인 영향을 준다는 것을 증명하였다. 따라서 대사증후군의 발생위험률을 낮추기 위한 방법으로는 규칙적인 걷기 참여와 함께 체중조절을 병행하는 것 이 보다 효과적으로 대사증후군 위험요인 및 발생위험률에 긍정적인 개선을 가져다 줄 것이다.

중심단어: 한국 성인, 걷기, 체질량지수, 대사증후군

\section{Conflicts of Interest}

No author has any conflict of interest.

\section{References}

1. Korea Centers for Disease Control and Prevention. Korea Health Statistics 2012: Korea National Health and Nutrition Examination Survey (KNHANES V-3). Seoul: Korea Centers for Disease Control and Prevention; 2012.

2. Török K, Szelényi Z, Pórszász J, Molnár D. Low physical performance in obese adolescent boys with metabolic syndrome. Int J Obes Relat Metab Disord 2001;25:966-70.

3. Ervin RB. Prevalence of metabolic syndrome among adults 20 years of age and over, by sex, age, race and ethnicity, and body mass index: United States, 2003-2006. Natl Health Stat Report 2009;13:1-8.

4. Graziani F, Cialdella P, Liuzzo G, Basile E, Brugaletta S, Pedicino D, et al. Cardiovascular risk in obesity: different activation of inflammation and immune system between obese and morbidly obese subjects. Eur J Intern Med 2011;22:418-23.

5. Eid WE. Obesity and type 2 diabetes mellitus in South Dakota: focused insight into prevalence, physiology and treatment. S D Med 2011:68-73.

6. Cheriyath P, Duan Y, Qian Z, Nambiar L, Liao D. Obesity, physical activity and the development of metabolic syndrome: the Atherosclerosis Risk in Communities study. Eur J Cardiovasc Prev Rehabil 2010;17:309-13.

7. Brage S, Wedderkopp N, Ekelund U, Franks PW, Wareham NJ, Andersen LB, et al. Features of the metabolic syndrome are associated with objectively measured physical activity and fitness in Danish Children: the European Youth Heart Study (EYHS). Diabetes Care 2004;27:2141-8.

8. Jurca R, Lamonte MJ, Church TS, Earnest CP, Fitzgerald SJ, Barlow $\mathrm{CE}$, et al. Associations of muscle strength and fitness with metabolic syndrome in men. Med Sci Sports Exerc 2004;36:1301-7.

9. Manson JE, Hu FB, Rich-Edwards JW, Colditz GA, Stampfer MJ, Willett WC, et al. A prospective study of walking as compared with vigorous exercise in the prevention of coronary heart disease in women. N Engl J Med 1999;341:650-8.

10. Ouyang P, Sung J, Kelemen MD, Hees PS, Deregis JR, Turner KL, et al. Relationships of insulin sensitivity with fatness and fitness and in older men and women. J Womens Health (Larchmt) 2004; 13:177-85

11. Wessel TR, Arant CB, Olson MB, Johnson BD, Reis SE, Sharaf BL, et al. Relationship of physical fitness vs body mass index with cor- 
onary artery disease and cardiovascular events in women. JAMA 2004;292:1179-87.

12. Kim DI, Kang DW, Park JH, Kim ES, Kim YM, Lee JA, et al. The relationship between muscular endurance fitness, cardiorespiratory fitness, body mass index and metabolic syndrome risk factors among male late-adolescents in Korea. The Korean Journal of Physical Education 2014;53:475-84.

13. Alberti KG, Eckel RH, Grundy SM, Zimmet PZ, Cleeman JI, Donato KA, et al. Harmonizing the metabolic syndrome: a joint interim statement of the International Diabetes Federation Task Force on Epidemiology and Prevention; National Heart, Lung, and Blood Institute; American Heart Association; World Heart Federation; International Atherosclerosis Society; and International Association for the Study of Obesity. Circulation 2009;120:1640-5.

14. Expert Panel on Detection, Evaluation, and Treatment of High Blood Cholesterol in Adults. Executive summary of the third report of the National Cholesterol Education Program (NCEP) expert panel on detection, evaluation, and treatment of high blood cholesterol in adults (Adult Treatment Panel III). JAMA 2001; 285:2486-97.

15. World Health Organization. Global recommendations on physical activity for health. Geneva: World Health Organization; 2010.

16. World Health Organization Western Pacific Region; International Association for the Study of Obesity; International Obesity Task Force. The Asia-Pacific perspective: redefining obesity and its treatment. Sydney: Health Communications Australia Pty Limited; 2000.

17. Goodpaster BH, Krishnaswami S, Harris TB, Katsiaras A, Kritchevsky SB, Simonsick EM, et al. Obesity, regional body fat distribution, and the metabolic syndrome in older men and women. Arch Intern Med 2005;165:777-83.

18. Anton SD, Duncan GE, Limacher MC, Martin AD, Perri MG. How much walking is needed to improve cardiorespiratory fitness? An examination of the 2008 Physical Activity Guidelines for Americans. Res Q Exerc Sport 2011;82:365-70.

19. Gregg EW, Gerzoff RB, Caspersen CJ, Williamson DF, Narayan KM. Relationship of walking to mortality among US adults with diabetes. Arch Intern Med 2003;163:1440-7.

20. Murphy MH, Nevill AM, Murtagh EM, Holder RL. The effect of walking on fitness, fatness and resting blood pressure: a meta-analysis of randomised, controlled trials. Prev Med 2007;44:377-85.

21. Marsh SA, Coombes JS. Exercise and the endothelial cell. Int J Cardiol 2005;99:165-9.

22. Duncan JJ, Farr JE, Upton SJ, Hagan RD, Oglesby ME, Blair SN. The effects of aerobic exercise on plasma catecholamines and blood pressure in patients with mild essential hypertension. JAMA 1985;254:2609-13.

23. Fritz T, Wändell P, Åberg H, Engfeldt P. Walking for exercise-does three times per week influence risk factors in type 2 diabetes? Diabetes Res Clin Pract 2006;71:21-7.

24. Barter P, Gotto AM, LaRosa JC, Maroni J, Szarek M, Grundy SM, et al. HDL cholesterol, very low levels of LDL cholesterol, and cardiovascular events. N Engl J Med 2007;357:1301-10.

25. Li TY, Rana JS, Manson JE, Willett WC, Stampfer MJ, Colditz GA, et al. Obesity as compared with physical activity in predicting risk of coronary heart disease in women. Circulation 2006;113: 499-506. 